\title{
ANALISIS BORAK DENGAN MENGGUNAKAN METODE KOMPARATOR WARNA DARI KULIT BUAH NAGA MERAH
}

\author{
Anindia Ajeng Nastiti, Qurrata Ayun, Eko Malis \\ Program Studi Kimia, Fakultas Matematika dan Ilmu Pengetahuan Alam \\ Universitas PGRI Banyuwangi \\ Email korespondensi*: qu_rrata@yahoo.co.id
}

September 2020

\begin{abstract}
ABSTRAK
Banyuwangi merupakan pemasok buah naga terbesar di pulau jawa yaitu dengan mencapai 12.936 ton pada tahun 2013 (BPS Kabupaten Banyuwangi, 2013), dari jumlah sebanyak itu dapat di akumulasi total kulit buah sebanyak $2.008-2.343$ ton dan yang sayangnya hanya dibuang sebagai sampah. Sehingga penelitian ini memanfaatkan kulit buah naga merah yang mempunyai zat warna merah (Antosianin) sebagai indikator alami borak pada makanan siap saji.

Kandungan antosianin yang tinggi pada kulit buah naga merah menjadikan pilihan sebagai indikator alami. Dengan perlakuan ekstraksi kulit buah naga merah menggunakan pelarut asam sitrat $0.4 \mathrm{M}$, waktu Maserasi 2 jam dan pada suhu $20^{\circ} \mathrm{C}$ menghasilkan kadar total antosianin antosianin sebanyak $12.747 \mathrm{ppm}$. Dimana hasil tersebut di peroleh menggunakan metode $\mathrm{pH}$ defferensi dengan menggunakan perbedaan $\mathrm{pH}$, yaitu $\mathrm{pH} 1$ dan $\mathrm{pH}$ 4.5. Pada $\mathrm{pH} 1$ antosianin akan berbentuk senyawa oxonium, sedangkan pada $\mathrm{pH}$ 4,5 antosianin akan berbentuk karbinol yang tak berwarna. Hasil analisis sampel sosis dan cilok yang beredar di kota Banyuwangi, menunjukkan bahwa sosis yang beredar dibeberapa toko di kota Banyuwangi tidak mengandung adanya borak namun hasil analisis pada cilok yang beredar di beberapa titik jalan kota Banyuwangi mengandung adanya borak. Analisis sebelumnya dibandingkan dengan validasi yang dilakukan di dinaskelautan danPerternakan.
\end{abstract}

Kata Kunci: Kulit Buah Naga Merah, Antosianin,Borak, Komparator Warna. 


\section{PENDAHULUAN}

Pemasok buah naga merah di Pulau Jawa salah satunya adalah perkebunan buah naga merah yang berada di Kabupaten Banyuwangi dengan produksi mencapai 12.936 ton pada tahun 2012 dan akan terus meningkat di tahun berikutnya (BPS Kabupaten Banyuwangi, 2013). Citramukti (2008) menjelaskan bagian dari buah naga $30-35 \%$ merupakan kulit buah, namun seringkali hanya dibuang sebagai sampah. Produksi buah naga secara nasional pada tahun 2012 jumlahnya mencapai 6.696 ton (Anonymous, 2013) dari jumlah sebanyak itu dapat diperoleh total kulit buah sebanyak $2.008-2.343$ ton yang sayangnya hanya dibuang sebagaisampah.

Kulit buah naga merah sering kali dibuang sebagai sampah. Sebenarnya, kulit buah naga memiliki banyak manfaat dengan kandungan antosianin yang tinggi. Kulit buah naga merah memiliki kandungan nutrisi, seperti karbohidrat, lemak, protein dan serat pagan. Ekstrak dari kulit buah naga merah ini ternyata mengandung kadar antosianin 26,4587 ppm (Handayani dan Rahmawati, 2012). Antosianin merupakan zat warna yang berperan untuk memberikan warna merah, yang berpotensi untuk digunakan sebagai zat pewarna alami untuk pangan dan dapat juga dijadikan sebagai alternatif pengganti warna sintetis yang lebih aman bagi kesehatan (Citramukti, 2008). Kulit buah naga merah selainmempunyai warna merah yang menarik, ternyata juga mempunyai kandungan antioksidan (Li et al, 2006). Antosianin merupakan zat warna merah yang terkandung pada kulit buah naga merah yang diperkirakan dapat digunakan untuk mendeteksi kandungan borak yang terdapat pada makanan.

Nevrianto (1991) menyebutkan bahwa Borak dinyatakan dapat mengganggu keseahatan bila digunakan dalam makanan, misalnya mie, bakso kerupuk. Efek negatif yang ditimbulkan dapat berjalan lama meskipun yang digunakan dalam jumlah sedikit. Jika tertelan borak dapat mengakibatkan efek pada susunan syaraf pusat, ginjal dan hati. Ginjal merupakan organ paling mudah mengalami kerusakan dibandingkan dengan organ lain. Dosis aman yang diperbolehkan dalam takaran normal sekitar $6-7 \mathrm{ppm}$, menyebabkan keracunan 20 - 100 ppm, dan dapat menyebabkan kematian 200 -1300ppm.

Penggunaan borak untuk pengawet bahan makanan dapat menyebabkan mual, muntah, diare, kejang perut, demam, pusing, dan lain - lain. Bagi yang mengkonsumsinya untuk jangka panjang dapat menyebabkan penyakit kanker, sebab zat pengawet tersebut sulit diuraikan oleh tubuh (Asterina, dkk). Makanan ringan yang sangat digemari masyarakat yaitu makanan siap saji contohnya saja sosis dan cilok.. Sehingga diperlukan identifikasi dan penetapan kadar borak pada makanan siap saji yang dijual di beberapa toko dan di titik jalan Kota Banyuwangi dengan memanfaatkan ekstraksi kulit buah naga 
merah sebagai indikaor warna.

Penelitian dilakukan untuk penentuan borak dengan metode komperator warna, karena lebih mudah dalam pengaplikasian pada sampel. Komparatorsendiri merupakan suatu alat ukur sederhana untuk mengetahui kisaran konsentrasi dari suatu analit. Konsentrasi analit diperoleh berdasarkan perbandingan warna antara larutan analit dengan warna pada komparator. Pada penelitan ini, yang akan diamati antara lain adalah pengaruh konsentrasi asam sitrat, pengaruh suhu, pengaruh lama waktu pada proses ekstraksi kulit buah naga merah sebagai penentu kadar antosianin. Hasi optimasil yang diperoleh dari proses ekstraksi digunakan sebagai indikator alami penentu kadar borak pada makanan menggunakan metode komperator warna.

\section{METODE PENELITIAN}

\subsection{Alat dan Bahan}

\subsubsection{Alat}

Mortal, pastel, gelas beaker, neraca analitik, botol vial gelap, botol semprot, corong gelas, pH meter, batang pengaduk, pipet mikro, pipet tetes, labu ukur, gelas ukur, tabung reaksi, spektrofotometer UV-Vis, Termometer, erlenmeyer, $\mathrm{pH}$ universal, spatula, cawan, hot plate, stirer, cool box, ball pipet, dan plat tetes.

Kulit buah naga merah, aquadest, tissue, $\mathrm{pH}$ standart 4, 7, dan 9, es balok, sosis, Cilok, alumunium foil, plastik krep, kertas saring, $\mathrm{HCl}, \mathrm{KOH}, \mathrm{CH}_{3} \mathrm{COONa}_{2} \mathrm{C}_{6} \mathrm{H}_{8} \mathrm{O}_{7} .2 \mathrm{H}_{2} \mathrm{O}$, $\mathrm{H}_{2} \mathrm{~B}_{4} \mathrm{O}_{7}, \mathrm{~K}_{2} \mathrm{HPO}_{4}, \mathrm{KH}_{2} \mathrm{PO}_{4}, \mathrm{KMnO}_{4}$, dan $\mathrm{H}_{3} \mathrm{PO}_{4}$. Sebanyak $2 \mathrm{~mL}$ hasil ekstraksi ditambahkan dengan $8 \mathrm{~mL}$ buffer $\mathrm{CH}_{3} \mathrm{COONa}$ dengan $\mathrm{pH} 1$ masukan dalam tabung reaksi. Kemudian didiamkan selama 15 menit kemudian diukur absorbansinya pada panjang gelombang $510 \mathrm{~nm}$ dan panjang gelombang $700 \mathrm{~nm}$, perlakuan sama untuk buffer $\mathrm{pH}$ 4,5. Absorbansi larutan sampel ditentukan dengan persamaan dibawahini;

$\mathrm{A}=\left(\mathrm{A}_{510}-\mathrm{A}_{700}\right) \mathrm{pH} 1-\left(\mathrm{A}_{510}-\mathrm{A}_{700}\right) \mathrm{pH} 4,5$

Kandungan antosianin pada sampel ditentukan dengan persamaan

Total Antosianin dimana :

$$
\mathrm{mg}=\frac{\mathrm{A} \times \mathrm{BM} \times \mathrm{DF} \times 1000}{\mathrm{~L}} \frac{\mathrm{E \times 1}}{\mathrm{L} \times 1}
$$

$$
\mathrm{BM}=\text { berat molekul Sianidin-3-glukosida }=449,2 \mathrm{~g} / \mathrm{mol} \mathrm{DF}=\text { faktor }
$$
pengenceran

$$
\begin{aligned}
\mathcal{E} & =\text { absorptivitas molar sianidin-3-glukosida }=26900 \mathrm{~L} \cdot \mathrm{mol}^{-1} \mathrm{~cm}^{-1} \\
1 & =\text { tebal kuvet }(\mathrm{cm})
\end{aligned}
$$

\subsubsection{Optimasi Konsentrasi Asam Sitrat Pada Proses Ekstraksi Kulit Buah}




\section{NagaMerah.}

Kulit buah naga yang sudah halus ditimbang sebanyak 10 gr kemudian dicampur dengan $50 \mathrm{~mL}$ variasi konsentrasi asam sitrat yang digunakan adalah $0.1 \mathrm{M}, 0.2 \mathrm{M}, 0.3 \mathrm{M}$, 0.4M dan $0.5 \mathrm{M}$, kemudian diaduk dan dimaserasi selama 3 jam pada suhu $35{ }^{\circ} \mathrm{C}$ selanjutnya disaring dengan menggunakan kertas saring. Hasil ekstraksi diuji kadar antosianin totalnya menggunakan metode 3.3.3.2.

\subsubsection{Optimasi Suhu Pada Proses Ekstraksi Kulit Buah NagaMerah.}

Konsentrasi yang diperoleh pada asam sitrat dengan perlakuan 3.3.3 dilajutkan dengan pengukuran variasi pada suhu, $15{ }^{\circ} \mathrm{C}, 20^{\circ} \mathrm{C}, 25^{\circ} \mathrm{C}, 30^{\circ} \mathrm{C}$, dan $35^{\circ} \mathrm{C}$. Hasil ekstraksi diuji kadar antosianin totalnya menggunakan metode 3.3.3.2.

\subsubsection{Optimasi Waktu Pada Proses Ekstraksi Kulit Buah NagaMerah}

Hasil dari optimasi suhu pada proses ekstraksi kulit buah naga merah dengan perlakuan 3.3.4 dilanjutkan dengan pengukuran variasi pada waktu lama ekstraksi yaitu 1 jam, 2 jam, 3 jam, 4 jam, dan 5 jam. Hasil ekstraksi diuji kadar antosianin totalnya menggunakan metode 3.3.3.2.

\subsubsection{Ekstraksi Maserasi Kulit Buah Naga Merah Dengan Pelarut Aquades}

Kulit buah naga yang sudah halus ditimbang sebanyak 10 gr kemudian dicampur dengan $50 \mathrm{~mL}$ aquades yang digunakan sebagai pelarut, kemudian diaduk dan dimaserasi selama 2 jam pada suhu $20{ }^{\circ} \mathrm{C}$ selanjutnya disaring dengan menggunakan kertas saring dan fitratnya ditampung dan dan didapatkan larutan ekstrak kulit buah naga merah.

\subsubsection{Pengaruh pH Terhadap Warna Pigmen Antosianin Pada Kulit Buah Naga} Merah.

Hasil dari optimasi suhu dan waktu pada proses ekstraksi kulit buah naga merah pada perlakuan 3.3.4 dan 3.3.5 dengan pelarut aquades kemudian dilanjutkan pengaruh variasi $\mathrm{pH}$ terhadap warna pigmen antosianin pada kulit buah naga merah dengan mengguanakan pelarut aquades yang telah dilakukan pada perlakuan 3.3.7 dengan variasi $\mathrm{pH} 3,4,5,6,7,8,9,10,11,12$, dan $\mathrm{pH} 13$ dengan menggunakan buffer fosfat.

\subsubsection{Pengaruh Asam Borak Terhadap Warna Larutan Ekstrak Sesudah PenambahanBuffer}

Metode dari pengaruh $\mathrm{pH}$ terhadap warna pigmen antosianin pada kulit buah naga merah pada perlakuan 3.3.6 dengan penambahan buffer fosfat dari $\mathrm{pH} 3-\mathrm{pH} 13$ kemudian ditambahkan dengan 500 ppm larutan asam borak dengan perbandingan volume beberapa larutan yaitu: $50 \mu \mathrm{L}$ hasil optimasi ekstraksi kulit buah naga dicampur dengan $100 \mu \mathrm{L}$ buffer 12 , dan $100 \mu \mathrm{L}$ larutan asam borak 500 ppm.

\subsubsection{Analisis FTIR}


Hasil ekstraksi dari hasil optimasi 3.3.5 di uji menggunakan FTIR

\subsubsection{Preparasi Pembuatan KomparatorBorak}

$50 \mu \mathrm{L}$ hasil optimasi ekstraksi kulit buah naga dicampur dengan $100 \mu \mathrm{L}$ buffer $12,100 \mu \mathrm{L}$ variasi asam borak 100, 200, 300, 400, 500, 600, 700, 800, 900, dan 1000 ppm, dan $5 \mu \mathrm{LMnO}_{4}$ 0.01 M dimasukan kedalam plat tetes. Ditunggu 10menit sampai terjadi perubahan warna. Kemudian dilakukan pemotretan warna- warna yang terbentuk pada larutan penyerap.

\subsubsection{Penentuan Kadar Borak PadaSampel}

\subsubsection{PreparasiSampel}

Sampel sosis berlabel A, B dan C dan sampel cilok berlabel A dan B yang diambil dibeberapa toko dan dititik jalan dikota Banyuwangi.

\subsubsection{Penentuan Kadar Borak DalamSampel}

Sampel sosis dan cilok yang sudah halus diambil $5 \mathrm{~g}$, kemudian ditambah aquadest sebanyak $50 \mathrm{~mL}$ dengan direndamen selama 30 menit dan selanjutnya disaring diambil filtranya. Untuk pengukuran selanjutnya dibutuhkan sebanyak 50 $\mu \mathrm{L}$ ekstrak, $100 \mu \mathrm{L}$ buffer, $100 \mu \mathrm{L}$ sampel makanan dan $5 \mu \mathrm{L} \mathrm{KMnO}_{4} 0,01 \mathrm{M}$ sebagai indikator dimasukan kedalam plat tetes. Ditunggu 15 menit sampai tejadi perubahan warna. Kemudian dilakukan pemotretan warna - warna yang terbentuk pada larutanpenyerap.

\subsubsection{Pembuatan Komparator Warna}

Komparator warna dibuat dengan cara melakukan pemotretan warna - warna yang terbentuk pada larutan penyerap.

\subsubsection{Validasi Kualitatif Borak}

Validasi kualitatif dilakukan dengan mengirim 3 sampel sosis ayam berlabel A, B, dan C dan sampel cilok berlabel A, dan B yang di ambil dibeberapa toko dan titik jalan dikota Banyuwangi

\section{HASIL DAN PEMBAHASAN}

Konsentrasi asam sitrat sangat berpengaruh terhadap kadar total antosianin pada kulit buah naga merah oleh karena itu saat penambahan konsentrasi dari0.1M-0.4 $\mathrm{M}$ menujukkan peningkatan kadar total antosianin yang sangat drastis. Diakibatkan saat penambahan konsentrasi asam sitrat yang semakin tinggi akan menjadikan terjadinya penurunan $\mathrm{pH}$ pada larutan ekstraksi. Sehingga menjadikan banyaknya pigmen antosianin berada dalam bentuk kation flaviliumatau oksonium yang berwarna oleh sebab itu 
pengukuran absorbansi akan menunjukkan jumlah antosianin yang semakin besar yaitu dari 1.085 ppm - 8.683 ppm dari nilai tersebut telah membuktikan bahwa konsentrasi asam sitrat sangat berpengaruh terhadap kadar antosianin pada kulit buah nagamerah.

Namun dilihat pada grafik tersebut saat penambahan asam sitrat pada konsentrasi 0.5 M mengalami penurunan yang sangat drastis dalam penentuan kadar total antosianin, di sebabkan saat penambahan konsentrasi asam sitrat $0.5 \mathrm{M}$ mengalami kejenuhan dalam melarutkan kadar antosianin pada kulit buah naga merah dimana semangkin keadaan asam suatu pelarut mengakibatkan kerusakan suatu senyawa antosianin atau pun di karenakan keadaan suatu pelarut mempunyai batas kemampuan untuk melarutkan bahan yang ada atau pelarut berada dalam titik jenuhnya, sehingga seberapa besar konsentrasi yang diberikan tidak dapat memberikan efek kenaikan kadar total antosianinekstrak.

Keadaan yang semakin asam menyebabkan semakin banyak dinding sel vakuola yang pecah sehingga pigmen antosianin semakin banyak yang terekstrak (Lidya Simanjuntak dkk, 2014). Keadaan yang semakin asam menyebabkan semakin banyaknya pigmen antosianin berada dalam bentuk kation flavilium atau oxonium yang berwarna lebih pekat (Setyaningrum, 2010). Golongan asam ini jika di kombinasikan dengan air dapat melarutkan zat-zat yang dapat larut pada pelarut polar contohnya Antosianin (Lazuardi, 2010). Penambahan asam sitrat sebesar 5\% dapat meningkatkan rendemen ekstrak antosianin sebesar 15\% dan menurunkan $\mathrm{pH}$ sehingga antosianin pada bahan lebih stabil(Pareira,2008).

\section{Pengaruh Suhu Terhadap Kadar TotalAntosianin}

Suhu sangat berpengaruh terhadap kesetabilan warna ekstrak buah naga merah. Semakin meningkatnya (tingginya) suhu dapat menyebabkan hilagnya glikosil pada antosianin dengan menghidrolisis ikatan glikosidik sehingga aglikon yang dihasilkan kurang stabil dan menyebabkan hilangnya warna pada antosianin. Oleh karena itu dalam penelitian ini menggunakan beberapa variasi suhu $15{ }^{\circ} \mathrm{C}, 20^{\circ} \mathrm{C}, 25{ }^{\circ} \mathrm{C}, 30{ }^{\circ} \mathrm{C}$ dan $35^{\circ} \mathrm{C}$ sebagai pengaruh kadar total antosianin. Hasil penelitian, suhu sangat berpengaruh terhadap ekstraksi kulit buah naga merah dalam menentukan kadar total antosianin sebagaimana data dibawahini:

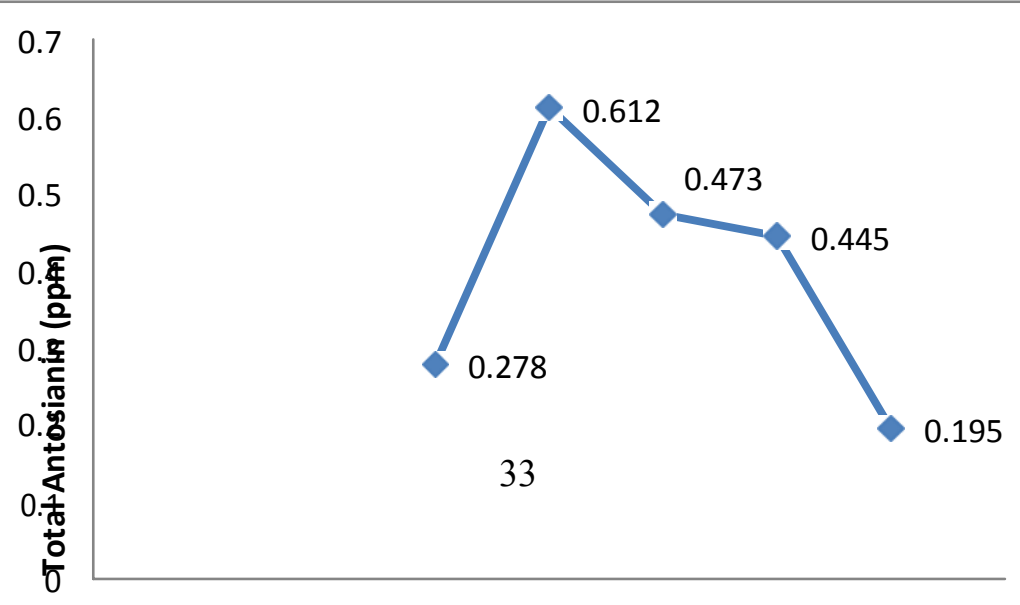


Dari gambar 4.2 diperoleh data bahwa variasi suhu yang menghasilkan kadar total antosianin paling besar adalah suhu $20{ }^{\circ} \mathrm{C}$ yaitu $0.612 \mathrm{ppm}$ dari pada suhu $15{ }^{\circ} \mathrm{C}, 25$ ${ }^{\circ} \mathrm{C}, 30{ }^{\circ} \mathrm{C}$ dan $35{ }^{\circ} \mathrm{C}$. Dilihat dari grafik diatas menunjukkan bahwa pengaruh suhu sangatlah berpengaruh terhadap penentuan kadar total antosianin pada kulit buah naga merah yaitu dari suhu $20{ }^{\circ} \mathrm{C}-35^{\circ} \mathrm{C}$ mengalami penurunan sangat drastis. Diakibatkan saat perlakuan variasi suhu, dari suhu yang rendah ke suhu tinggi akan mengakibatkan penurunan stabilitas warna antosianin dari ekstraksi kulit buah naga merah. Sehingga mengakibatkan warna pigmen Antosianin berada dalam kerusakan gugus kromofor yang menyebabkan warna pigmen pada ekstraksi kulit buah naga merah rusak dan terlihat lebih pucat.

\section{Pengaruh Waktu Terhadap Kadar TotalAntosianin}

Waktu sangat berpengaruh terhadap kesetabilan warna ekstrak buah naga merah. Semakin lamanyan waktu ekstraki maka menyebabkan terdegradasi pada senyawa antosianin sehingga mengakibatkan kurangnya kadar total antosianin. Oleh karena itu dalam penelitian ini menggunakan beberapa variasi waktu rendamen 1 jam, 2 jam, jam 3, jam 4, dan 5 jam sebagai pengaruh kadar total antosianin. Hasil penelitian, waktu rendamen sangat berpengaruh terhadap ekstraksi kulit buah naga merah dalam menentukan kadar total antosianin sebagaimana data dibawah ini:

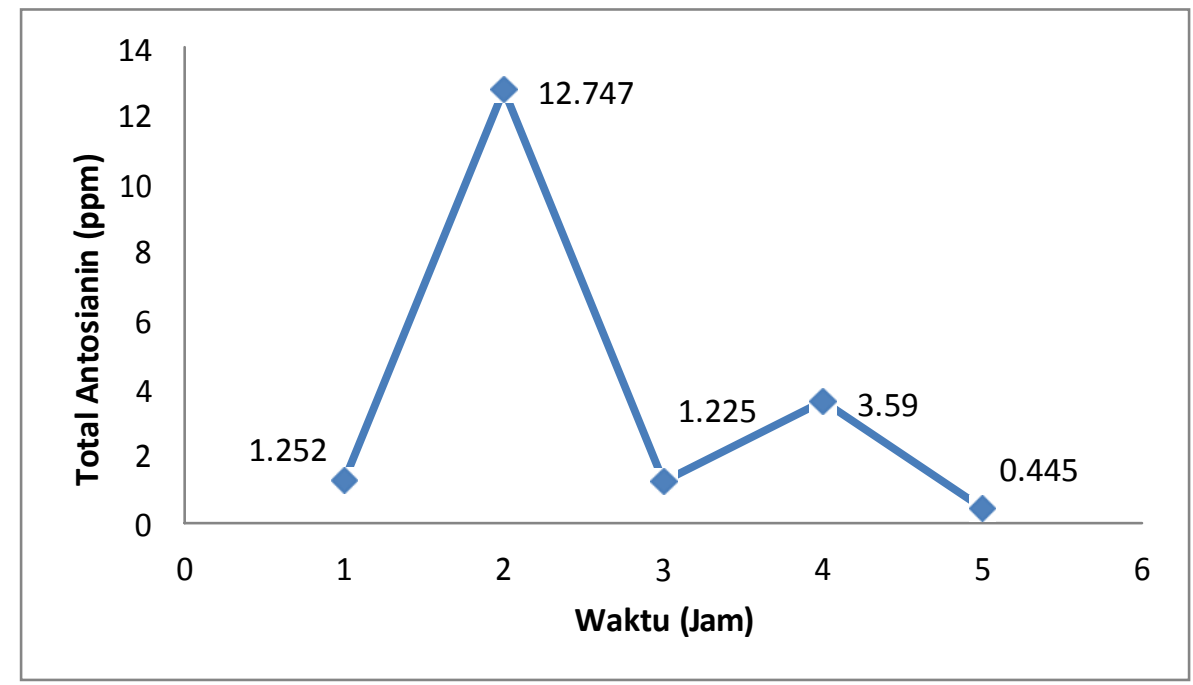

Gambar 4.2 Grafik Pengaruh Variasi Waktu 
Dari gambar 4.3 diperoleh data bahwa variasi waktu rendamen yang menghasilkan kadar total antosianin paling besar adalah 2 jam yaitu 13.109 ppm dari pada waktu rendamen 1 jam, 3 jam, 4 jam, dan 5 jam. Kadar total antosianin selama rendamen 1 jam lebih kecil pada rendamen selama 2 jam hal tersebut dikarenakan kontak antar zat terlarut dengan pelarut semakin lama akan menyebabkan banyak zat terlarut yang akan terambil.

Ekstrak warna merah yang diperoleh dari kulit buah naga bersifat tidak stabil terhadap lama waktu rendamen, dilihat dari grafik di atas waktu rendamen dari 2 jam - 5 jam mengalami panurunan yang sangat drastis, hal ini di sebabkan bahwa terlalu lama waktu rendamen akan menyebabkan degradasi sehingga warna antosianin yang terkandung dalam kulit buah naga merah akan mengalami penurunan warna pigmen. Sehingga pengukuran absorbansi akan menunjukkan kadar total antosianin yang semakin menurun. Peningkatan aktivitas antioksidan (antosianin) tersebut akan berhenti hingga lama ekstraksi sampai pada titik tertentu yaitu pada lama ekstraksi yang digunakan sudah mencapai titik optimumnya yaitu pada rendamen $2 \mathrm{jam}$.

Semakin lama pula bahan terpapar radiasi gelombang mikro yang mengakibatkan pecahnya jaringan bahan sehingga mengeluarkan zat terlarut (solute) ke dalam pelarut (solvent) (Navas et al., 2012). Penggunaan waktu yangterlalu lama perlu dihindari karena dapat meningkatkan degradasi senyawa antosanin (Windha Ingrath, dkk, 2015).

\section{Pengaruh pH Terhadap Warna Pigmen Antosianin Pada Kulit Buah Naga Merah.}

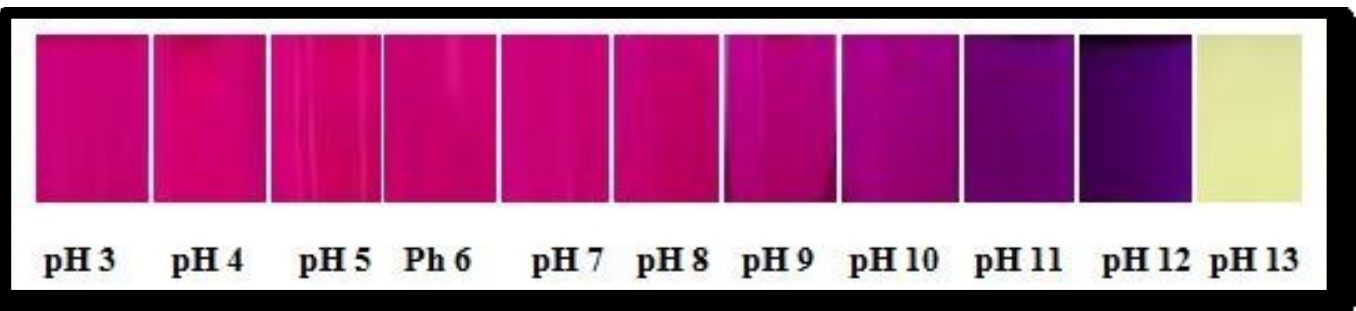

Hasil penelitian, pH sangat berpengaruh terhadap ekstraksi kulit buah naga merah dalam menentukan warna pigmen antosianin sebagaimana data dibawahini:

Gambar 4.3. Pengaruh $\mathrm{pH}$ terhadap ekstraksi kulit buah naga merah.

Dilihat bahwa penambahan buffer fosfat pada ekstraksi kulit buah naga merah dari $\mathrm{pH}$ asam ke $\mathrm{pH}$ basa menunjukan perubahan warna dari merah muda, keungguan dan kuning, sehingga semakin tinggi nilai $\mathrm{pH}$ maka warna pigmen antosianin terlihat semakin tidak jelas namun warna antosiani kulit buah naga merah lebih mencolok saat penambahan buffer fosfat $\mathrm{pH} 12$ dan kepekatan warna yang terbentuk dapat mempermudah pembentukan komparator warna

Menurut Markakis (1982), antosianin lebih stabil dalam larutan asam dibanding 
dalam larutan alkali atau netral. Pada larutan asam, antosianin bersifat stabil, pada larutan asam kuat antosianin sangat stabil. Dalam suasana asam, antosianin berwarna merahoranye sedangkan dalam suasana basa antosianin berwarna biru-ungu atau kadang kadang kuning (Eskin 1979)

\section{Pengaruh Asam Borak Terhadap Warna Larutan Ekstrak Sesudah Penambahan Buffer}

Pengaruh asam borak terhadap warna pigmen ekstrak kulit buah naga merah sesudah penambahan buffer dilakukan dengan tujuan memastikan berapa besar ektrak kulit buah naga merah tersebut berpengaruh terhadap identifikasi asam borak $\left(\mathrm{H}_{3} \mathrm{BO}_{3}\right)$, adapun asam borak yang digunakan yaitu 500 ppm dengan menuangkannya ke tabung reaksi yang sebelumnya telah terisi dengan campuran antara ekstrak kulit buah naga merah dan variasi buffer fosfat $\mathrm{pH} 3$ - 13. Adapun data yang di peroleh di bawah ini.
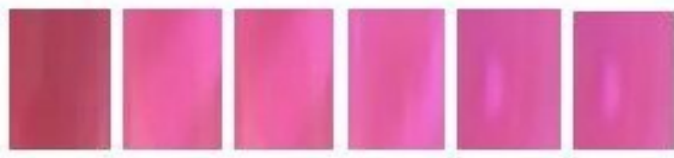

$\mathrm{pH} 3$
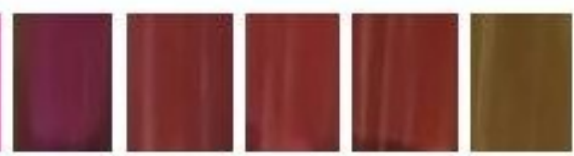

Gambar 4.4 Pengaruh Asam Borak Terhadap Warna Larutan Sesudah Penambahan Buffer

Dengan konsentrasi asam borak yang telah tercampur adalah $500 \mathrm{ppm}$, dari masing - masing variasi $\mathrm{pH}$ menampakan warna yang sedikit berubah. Oleh karena itu di lakukan penambahan indikator sintetis sebagai mempermudah dalam mengidentifikasi suatu analit. Telah diketahui bahwa indikator alami merupakan bahan alam yang mudahrusak.

\section{Analisis FTIR}

Struktur molekul antosianin yang digunakan sebagai acuan untuk melihat ada atau tidaknya senyawa antosianin yang terdapat dalam kulit buah naga merah. Adapun data yang menunjukkan kandungan antosianin menggunakan analisis FTIR gambar4.5: 


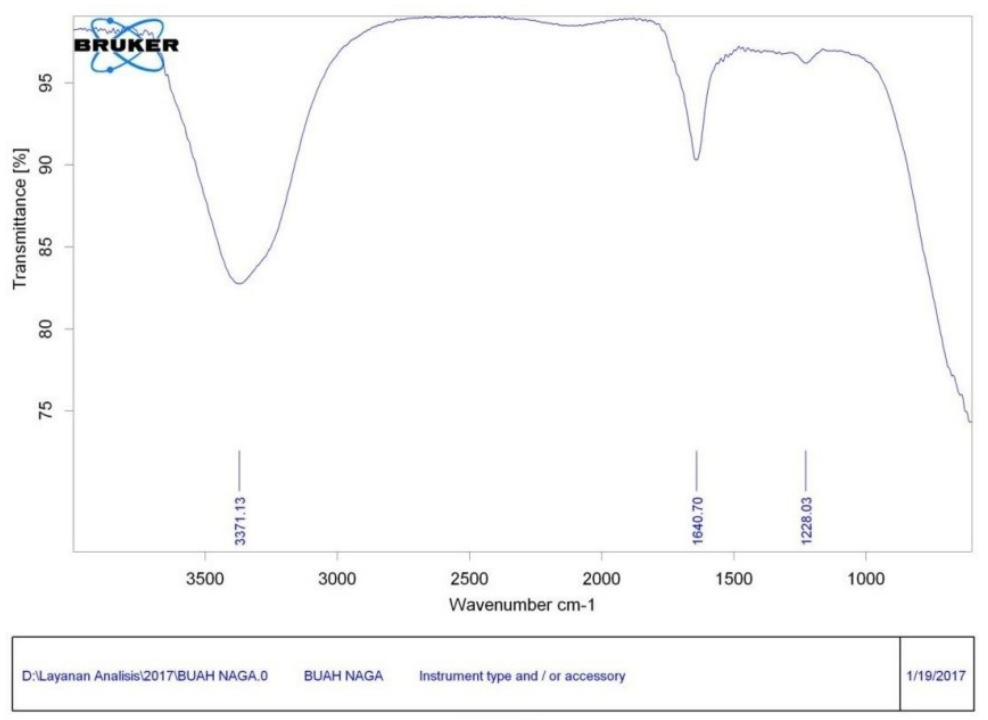

Gambar 4.5 Hasil FTIR.

Dari grafik diatas menunjukkan bahwa data FTIR yng menunjukkan puncak $1228.03 \mathrm{~cm}^{-1}$ yaitu (C-O, C-N) sesuai dengan puncak antosianin seperti yang dilaporkahasil yang diperoleh dari ekstrak kulit buah naga merah menunjukkan adanya serapan pada bilangan gelombang $3371,13 \mathrm{~cm}^{-1}$ yang menunjukkan adanya gugus $(\mathrm{O}-\mathrm{H})$, dan puncak menunnjukkan adanya gugus $(\mathrm{C}=\mathrm{N})$ pada serapan $1640,70 \mathrm{~cm}^{-1}$ dan dan puncak ke-3 yang menunjukkan adanya gugus $(\mathrm{C}-\mathrm{O}, \mathrm{O}-\mathrm{H})$ pada bilangan gelombang $1228.03 \mathrm{~cm}^{-1}$. Serapan yang diperoleh dari ekstrak kulit buah naga merah ini telah menunjukkan adanya senyawa antosianin dalam ekstrak kulit buah naga merah yang telah dihasilkan yaitu adanya gugus-gugus $\mathrm{O}-\mathrm{H}, \mathrm{C}=\mathrm{N}, \mathrm{C}-\mathrm{O}$, dan $\mathrm{C}-\mathrm{N}$. Kandungan antosianin pada kulit buah naga merah dikuatkan oleh penelitaian ilmuawan diantaranya. (Harborne, 1987) Secara kimia semua antosianin merupakan turunan suatu struktur aromatik tunggal, yaitu sianidin, dan semuanya terbentuk dari pigmen sianidin ini dengan penambahan atau pengurangan gugus hidroksil atau dengan metilisasi atau glikosilasi. Kulit buah naga daging merah mengandung pigmen antosianin berjenis sianidin 3-ramnosil glukosida 5glukosida (Saati, E.A.2002).

\section{Preparasi Pembuatan KomparatorBorak}

Komparator warna borak digunakan untuk mengetahui kisaran konsentrasi yang dapat ditentukan konsentrasinya melalui perubahan intensitas warna pada kadar borak pada makanan (sampel).

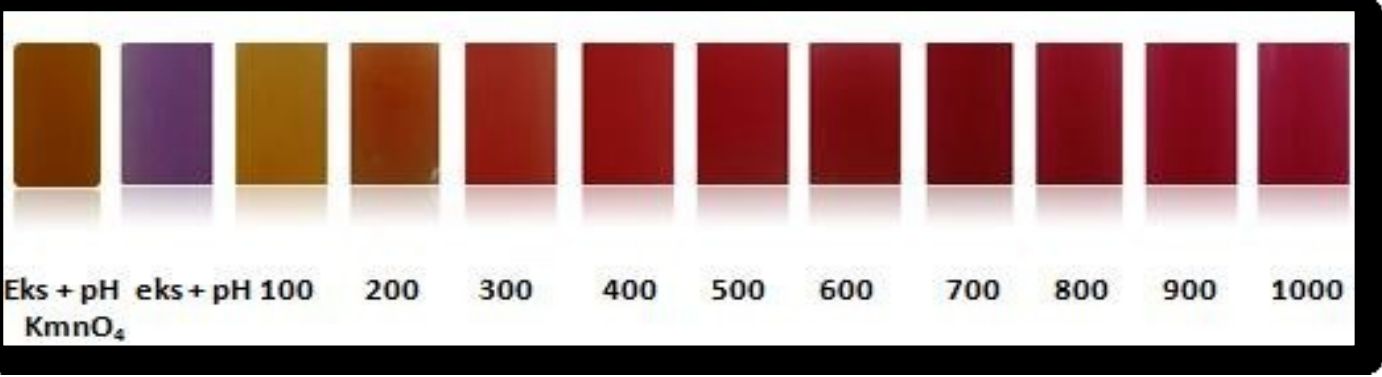


Gambar 4.6 Komparator warna boraks dari konsentrasi 100 ppm - 1000 ppm.

Dari gambar diatas dapat digunakan sebagai tolak ukur untuk menentukan kadar boraks pada sampel dari kisaran konsentrasi 100 ppm - 1000 ppm. Dari gambar diatas menunjukkan semakin banyak kandungan boraks maka semakin pekat pula yang terbentuk.

\section{Analisis Borak pada sampel sosis dan Cilok}

Dari hasil penelitian dinyatakan tidak mengandung borak ataupun negatif. Adapun hasil penelitian pada 3 sampel sosis dan 2 sampel cilok yang diambil di beberapa toko dan dititik jalan kota Banyuwangi. Dengan sampel sosis dan cilok masing-masing 3 kali pengulangan yang berlabelkan A, B, danC.

\section{KESIMPULAN}

Berdasarkan hasil penelitian dapat ditarik beberapa kesimpulan sebagai berikut:

1. Ekstraksi kulit buah naga merah menggunakan pelarut asam sitrat $0.4 \mathrm{M}$, waktu Maserasi 2 jam dan pada suhu $20{ }^{\circ} \mathrm{C}$ menghasilkan kadar total antosianin antosianin sebanyak $12.747 \mathrm{ppm}$.

2. Ekstraksi kulit buah naga merah menunjukan warna lebih menunjukan perubahan warna pada $\mathrm{pH} 12$ yaitu warna ungu.

\section{Saran}

Berdasarkan hasil-hasil penelitian dapat di tarik beberapa saran sebagai berikut:

Perlu penelitian lebih lanjut tentang kandungan boraks yang beredar di beberapa toko sekitar Kota Banyuwangi dengan menggunakan metode atau instrument yang lain. 


\section{DAFTAR PUSTAKA}

Asterina, Elmatris, dan Eldrinaldi. 2008. Identifikasi dan Penentuan Kadar Boraks pada Mie Basah yang Beredar di Beberapa Pasar di Kota Padang. Majalah Kedokteran Andalan. No. 2, Vol.32.

Astuti, Prima et al. 2012. Pemanfaatan Kulit Buah Naga (Dragon Fruit) Sebagai Pewarna Alami Makanan Pengganti Pewarna Sintetis. Jurnal Bahan Alam Terbuka. ISSN 2303-0623. Vol.1 No.2

Busboom, J. R. and R. A. Field. 2003. Homemade Meat, Poultry and Game Sausage. Washington State University. Washington.

Cahyadi, W. 2008. Analisis dan Aspek Kesehatan Bahan Tambahan Pangan.Bumi Aksara : Jakarta.

Citramukti, I. 2008. Ekstraksi dan uji kualitas pigmen antosianin pada kulit buah naga merah (Hylocereus costaricensis). Skripsi.Jurusan Teknologi Hasil Pertanian, Fakultas

Hasanudin. 2001.Penelitian Penerapan Zat Warna Alam dan Kombinasinya pada Produk Batik.Balai Besar Penelitiandan Pengembangan Industri Kerajinan dan Batik. Yogyakarta.

Lazuardi, Rene Nursaerah Mulki. 2010. Mempelajari Ekstraksi Pigmen Antosianin dari Kulit Manggis (Garcinia mangostana L.) dengan Berbagai Jenis Pelarut. Skripsi. Fakultas Teknik. Jurusan Teknologi Pangan Universitas Pasundan:Bandung.

Lidya Simanjuntak, Chairina Sinaga, Fatimah et al,2014. Ekstraksi Pigmen Antosianin Dari Kulit Buah Naga Merah (Hylocereus Polyrhizus). Jurnal Teknik Kimia USU.

Li, C.W., et al. 2006. Antioxidant and antiproliferative activities of red pitaya. Journal Food Chemistry. Vol 95: 319-327.

Putri, Ni Ketut Meidayanti et al. 2015. Aktivitas Antioksidan Antosianin Dalam Ekstrak Etanol Kulit Buah Naga Super Merah (Hylocereus costaricensis) dan Analisis Kadar Totalnya. Jurnal Kimia, Vol. 9, No. 2

Ponting, J. D., 1960. The Control Of Enzymatic Browning Fruit, in Food Enzymes. Ed., H. W. Schultz,pp 105-124.

Rahmawati Asri, Handayani Prima Astuti. 2012. Pemanfaatan Kulit Buah Naga (Dragon Fruit) Sebagai Pewarna Alami Makanan Pengganti Pewarna Sintetis. Program Studi Teknik Kimia, Fakultas Teknik, Universitas Negeri Semarang. Semarang.

Saneto, B. 2005. Karakterisasi kulit buah naga merah (Hylocereus polyrhizus).Jurnal Agarika. Vol 2: 143-149.

Schecter,I.barzilai,I.L.,anda Bulatov,V.,1997, On line Remote Prediction of Gasoline Properties by Combined Optical Method, Ana.Chim.Acta, 339, p,193-199 
Setyaningrum, A., 2010, Kapasitas Antiradikal Ekstrak Antosianin Buah Salam (Syzygium Polyanthum) Segar dengan Variasi Proporsi Pelarut, Jurusan Ilmu dan Teknologi Pangan UNS, Solo

Vargas, F. Natural Pigments: Carotenoids, Anthocyanins, and Betalains- Characteristics, Biosynthesis, Processing, and Stability. Critical Reviews in Food Science and Nutrition.2000; 40

Waladi et al. 2015. Pemanfaatan Kulit Buah Naga Merah (Hylocereus polyrhizus) Sebagai Bahan Tambahan Dalam Pembuatan Es Krim. Jom Faperta, Vol. 2, No. 1.

Widyaningsih, T.D. \& E.S. Murtini. 2006. Alternatif pengganti formalin pada pangan. Cetakan I. Trubus Agrisarana, Surabaya

Windha I, Wahyunanto, Rini et al, 2015. Ekstraksi Pigmen Antosianin Dari Kulit Buah Naga Merah (Hylocereus costaricensis) Sebagai Pewarna Alami Makanan Dengan Menggunakan Microwave (Kajian Waktu Pemanasan Dengan Microwave Dan Penambahan Rasio Pelarut Aquades Dan Asam Sitrat). Jurnal Bioproses Komoditas Tropis Vol. 3 No. 3,

Woodward,G, et al. 2009. "Anthocyanin stability and recovery: implications for the analysis of clinical and experimental samples".J. Agric. FoodChem.57(12):5271-8. 